\title{
Business prospects and challenges in Haor areas of Bangladesh
}

\author{
$\bowtie$ Md. Taj Uddin ${ }^{1}$, Najmul Hossain ${ }^{2}$ and Aurup Ratan Dhar ${ }^{1}$ \\ ${ }^{1}$ Department of Agricultural Economics, Bangladesh Agricultural University, Mymensingh-2202, Bangladesh \\ ${ }^{2}$ Friedrich Naumann Foundation (FNF), Dhaka
}

\begin{tabular}{|c|c|}
\hline ARTICLE INFO open ${ }^{\text {access }}$ & Abstract \\
\hline $\begin{array}{l}\text { Article history: } \\
\text { Received : } 08 \text { November } 2018 \\
\text { Accepted : } 19 \text { February } 2019 \\
\text { Published: } 31 \text { March } 2019 \\
\end{array}$ & \multirow{3}{*}{ 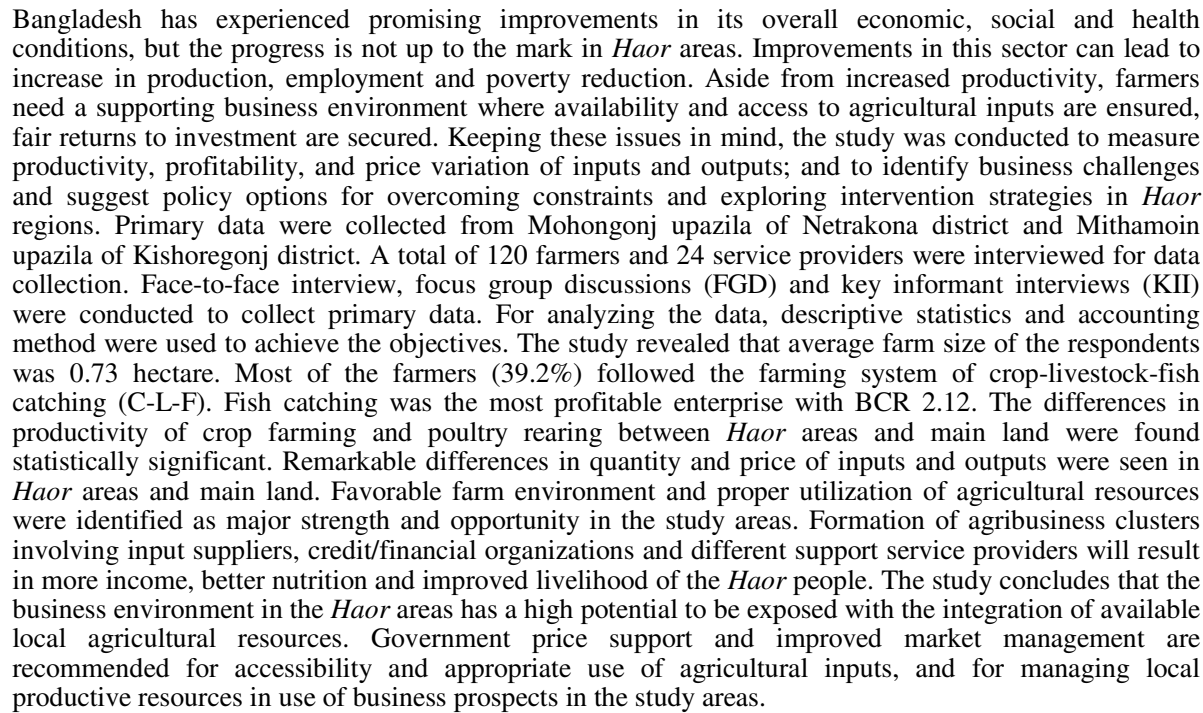 } \\
\hline $\begin{array}{l}\text { Keywords: } \\
\text { Haor, productivity, profitability, } \\
\text { business prospects, challenges }\end{array}$ & \\
\hline 凶: tajbau@yahoo.com & \\
\hline
\end{tabular}

\section{Introduction}

Bangladesh has witnessed respectable improvements in its economic, social and health conditions with annual GDP growth of $6.6 \%$ (WB, 2016). While the overall conditions of the country are promising, those residing in the Haor areas have not yet enjoyed the same level of relative or absolute progress. Haor is basically very low lying river basin area below the level of flood plain, which is also similar to swamp land covered by water almost six months of a year starting from the monsoon (Sharma, 2010). The Haor areas of north-eastern region in Bangladesh cover about 2.0 million hectare of area and accommodate about 19.4 million people. There are about 373 Haors located in the districts of Sunamganj, Sylhet, Kishoreganj, Habiganj, Netrakona, Maulvibazar and Brahmanbaria. These 373 Haors cover an area of about 858 thousand hectare which is around $43 \%$ of the total area of the Haor region (MoWR, 2012). Farming is the major economic activity of the Haor region. Improvements in this sector can lead to increase in production, employment and poverty reduction. Aside from increased productivity through improved technology, farmers need a supporting business environment where availability and access to agricultural inputs are ensured. In addition, farmers should be able to sell their products that yield fair returns to their investment.

The Haor region has long been lagging behind mainstream national development although the economic development of Bangladesh is moving steadily at a moderate pace. It is difficult to foresee the country's overall progress without the development of the Haor region as it covers a major part of the country and population which deserves special development initiatives. Since Boro rice is the only crop produced annually in the Haor area, the current economic system for non-aquatic resources offers very limited potential in terms of poverty alleviation. This single crop remains under the constant threat of partial to complete damage from the early on rush of flash floods. Fish catching is the important economic practice in these Haor areas. It is beyond doubt that suitable business environment will autonomously push the Haor areas to the light of development. The findings of the study will be used to design intervention strategies aimed at reducing the

\section{Cite this article}

Uddin, M.T., Hossain, N. and Dhar, A.R. 2019. Business prospects and challenges in Haor areas of Bangladesh. Journal of Bangladesh Agricultural University, 17(1): 65-72. https://doi.org/10.3329/jbau.v17i1.40665 
constraints of farming in the Haor regions. The range of activities may include advocacy and awareness creation at the local and national level, promote policy changes to alleviate the business constraints.

Relation of such condition has been depicted in a number of studies to take stock of existing research that are available and will highlight the need for present research which are:

Nowreen et al. (2013) evaluated the change of future climate extremes for the Haor basin area of Bangladesh and experienced the highest variability in both rainfall and temperature during the pre-monsoon season when flash floods normally occurred. Parvin (2013) performed an economic analysis of farm and non-farm activities with their income linkages in Dingaputa Haor of Netrokona district, and found that project participants' farm and non-farm income was higher as compared to the non-project participants' income. Khan et al. (2012) identified the impacts of flood on crop production in Haor areas of Kishoreganj district and revealed that Boro rice in Rabi season was damaged by flash flood due to unavailability of controlling measures. Alam et al. (2011) conducted a study on crop production in the Haor areas of Bangladesh and reported rice based potential cropping patterns; and Sharma (2010) explored the scenario of Haor vulnerabilities and other obstacles for sustainable livelihood development in Kishoreganj district and showed that $71 \%$ Haor households were effectively landless where $78.9 \%$ households suffered from food insecurity.

The above mentioned literature clearly indicate that a number of studies have been conducted on economic and livelihood prospect of Haor areas but there is no specific study on business prospects and potential in Haor areas. Therefore, the study will be very helpful to fill the research gap and add valuable information to the existing knowledge. The overall goal of the research was to address business prospects and challenges in Haor regions. The specific objectives of the study were: i) to measure productivity, profitability, and price variation of inputs and outputs; and ii) to identify business challenges and suggest policy options for overcoming constraints and exploring intervention strategies in Haor regions.

\section{Materials and Methods}

\section{Selection of the study area}

Primary data were collected from Mohongonj Upazila of Netrakona district and Mithamoin Upazila of Kishoregonj district. Four (04) villages of two (02) unions of each upazila (Gaglajore and Suair unions of Mohongonj upazila; and Mithamoin and Ghagra unions of Mithamoin Upazila) were taken under consideration. Thus a total of eight (08) villages were selected as study areas. These regions were selected for the study because they are very close to the Haor water bodies, dependent on rich natural resources, bounty of diversified farming systems and have favourable agribusiness environment.

\section{Sampling technique and sample size}

Total 120 farmers were interviewed following stratified random sampling based on farm size. Fifteen sample respondents of each village were interviewed for collecting necessary data and information. Also, 12 service providers from each Upazila, i.e., a total of 24 service providers were interviewed for data collection.

\section{Collection of data and information}

Field survey method through face-to-face interview using pre-tested structured questionnaire was used to collect primary data from the sample farmers. Moreover, a total of 8 focus group discussions (FGD) and 4 key informant interviews (KII) were conducted in each district with different stakeholders like, representatives of supporting institutions i.e., DAE, DLO, DoF officials, NGOs, input dealers, Upazila food office, rice millers and other market actors. The questionnaires were constructed and pre-tested for necessary modifications before starting the data collection. Besides, secondary information having relevance with this study were also used.

\section{Analytical techniques}

After collecting necessary data, those were classified, edited and coded. For analyzing the data, descriptive statistics (i.e., sum, average, percentages, ratios, t-test, etc.) and accounting method (i.e., profitability analysis) were used to achieve the objectives.

Profitability of crop production per hectare, from the view point of individual farmers was measured in terms of gross return $(\mathrm{GR}=\mathrm{P} \times \mathrm{Q})$, gross margin $(\mathrm{GM}=\mathrm{GR}-$ TVC), net return (NR $=\mathrm{GR}-\mathrm{TC}$ ) and benefit cost ratio $(\mathrm{BCR}=\mathrm{GR} \div \mathrm{TC})$ (Dillon and Hardaker, 1993).

Where, $\mathrm{GR}=$ Gross return (Tk.); GM = Gross margin (Tk.); NR = Net return (Tk.); BCR = Benefit cost ratio; $\mathrm{P}=$ Sales price of the product $(\mathrm{Tk}.) ; \mathrm{Q}=$ Yield per hectare (unit); TVC $=$ Total variable cost; TFC $=$ Total fixed cost (Tk.); and TC = Total cost (Tk.).

Moreover, SWOT analysis (Gürel and Tat, 2017) was done to evaluate the strengths, weaknesses, opportunities and threats to identify the internal and external factors that are favorable and unfavorable to achieve the objectives of this research. Finally, recommendations were provided in the form of recommendation matrix (Dhar, 2016) to point out the facts of intervention exploring the business opportunities in Haor areas.

\section{Results and Discussion}

\section{Demographic information of the respondents}

The demographic information is represented in Table 1. It is seen that average family size of the respondents was 6.0 (higher than national average of 4.06 according to HIES, 2017). The study revealed that $66.7 \%$ member of the household was male and $33.3 \%$ were female indicating the average male-female ratio as 2:1. Average farm size of the respondents was 0.73 ha. In terms of respondents surveyed, $98.3 \%$ was male where only $1.7 \%$ 
was female. Majority of them (49.1\%) were under the age group of 16 to 55 years that are considered as active and working group. Most of the respondents were illiterate $(43.3 \%)$ whereas $35.9 \%$ completed primary level of education. It was found that there were less educational facilities in the Haor areas compared to the main land. Dreadful transportation system played a major role behind most of the farmers' being illiterate in the study areas. In terms of farming activities, $95.8 \%$, $70.0 \%, 40.8 \%$ and $60.8 \%$ respondents were involved with crop, livestock, poultry and fish catching, respectively. Almost all of the farmers were engaged in Boro rice production in the pre-monsoon period while in the monsoon period, almost three-fifth of them got involved in fish catching also (Table 1).

Table 1. Demographic information of the respondents

\begin{tabular}{|c|c|c|}
\hline \multicolumn{2}{|c|}{ Particulars about the respondents } & $\begin{array}{l}\text { Percentages }(\%) \text { of } \\
\text { respondents }\end{array}$ \\
\hline \multirow{2}{*}{\multicolumn{2}{|c|}{ Family size (no.) }} & 6.0 \\
\hline & & $\begin{array}{c}\text { (Male: } 66.7 \% \text {; Female: } \\
33.3 \% \text { ) }\end{array}$ \\
\hline \multicolumn{2}{|c|}{ Farm size (ha) } & 0.73 \\
\hline \multirow{2}{*}{ Sex } & Male & 98.3 \\
\hline & Female & 1.7 \\
\hline \multirow{4}{*}{ Age } & Below 5 years & 3.7 \\
\hline & 5 to 15 years & 18.2 \\
\hline & 16 to 55 years & 49.1 \\
\hline & Above 55 years & 29.0 \\
\hline \multirow{5}{*}{$\begin{array}{l}\text { Educational } \\
\text { level } \\
\text { attained }\end{array}$} & Illiterate & 43.3 \\
\hline & Primary & 35.9 \\
\hline & Secondary & 15.0 \\
\hline & Higher secondary & 5.0 \\
\hline & Graduation & 0.8 \\
\hline \multirow{4}{*}{$\begin{array}{l}\text { Involvement } \\
\text { with } \\
\text { farming } \\
\text { activities }\end{array}$} & Crop & 95.8 \\
\hline & Livestock & 70.0 \\
\hline & Poultry & 40.8 \\
\hline & Fish catching & 60.8 \\
\hline
\end{tabular}

Source: Field survey, 2016.

\section{Major farming systems}

The major farming systems identified in the study areas were Crop-Livestock-Poultry (C-L-P), Crop-LivestockFish catching (C-L-F), Crop-Poultry-Fish catching (C-P-
F) and Crop-Livestock-Poultry-Fish catching (C-L-P-F) which were followed by $18.3 \%, 39.2 \%, 30.0 \%$ and $12.5 \%$ respondents, respectively (Table 2). It is evident that, crop production and fish catching is almost common in all the farming systems in Haor areas. Islam et al. (2011) also exposed the similar findings where the authors found six dominant farming systems in Dingapota Haor of Netrokona district which were: croplivestock-poultry-fish catching (C-L-P-FC), croplivestock-fish catching-labour selling (C-L-FC-LS), fish catching-labour selling (FC-LS), crop-livestock (C-L), crop-livestock-fish catching (C-L-FC) and croplivestock-poultry (C-L-P).

Table 2. Major farming systems in the study areas

\begin{tabular}{lcc}
\hline Farming systems & $\begin{array}{c}\text { No. of } \\
\text { farmers } \\
(\mathrm{n}=120)\end{array}$ & $\begin{array}{c}\text { Percentages } \\
(\%) \\
\text { of farmers }\end{array}$ \\
\hline $\begin{array}{l}\text { Crop-Livestock-Poultry (C-L-P) } \\
\text { Crop-Livestock-Fish catching } \\
\text { (C-L-F) }\end{array}$ & 22 & 18.3 \\
$\begin{array}{l}\text { Crop-Poultry-Fish catching } \\
\text { (C-P-F) }\end{array}$ & 47 & 39.2 \\
$\begin{array}{l}\text { Crop-Livestock-Poultry-Fish } \\
\text { catching (C-L-P-F) }\end{array}$ & 15 & 30.0 \\
\hline
\end{tabular}

Source: Field survey, 2016.

Productivity and Profitability of agricultural enterprises

Table 3 represents the average profitability of different agricultural enterprises under the major farming systems. It is seen that BCR of crop production (Boro rice), livestock rearing, poultry farming and fish catching were $1.27,1.26,1.26$ and 2.12 , respectively. A value of BCR more than 1 denotes the return as profitable. So it can be said that return from the enterprises were profitable. The results imply that the respondents received Tk. 127, Tk. 126, Tk. 126 and Tk. 212 from investing Tk. 100 in case of crop production, livestock rearing, poultry farming and fish catching, respectively. It was experienced that fish catching was the most profitable agricultural enterprise in the study areas.

Table 3. Profitability of agricultural enterprises under the major farming systems

\begin{tabular}{llcccc}
\hline \multirow{2}{*}{ Particulars } & \multicolumn{4}{c}{ Agricultural enterprises } \\
\cline { 3 - 6 } & $\begin{array}{c}\text { Crop production (Boro rice) } \\
\text { (Tk./ha) }\end{array}$ & $\begin{array}{c}\text { Livestock rearing } \\
\text { (Tk./animal/year) }\end{array}$ & $\begin{array}{c}\text { Poultry farming } \\
\text { (Tk./bird/year) }\end{array}$ & $\begin{array}{c}\text { Fish catching } \\
\text { (Tk./ha) }\end{array}$ \\
\hline i. & Total variable cost & 95208 & 91307 & 3816 & 38117 \\
ii. & Total fixed cost & 8974 & 25545 & 3495 & 2014 \\
iii. & Total cost (i + ii) & 104182 & 116852 & 7311 & 40131 \\
iv. & Gross return & 132485 & 147549 & 9224 & 85078 \\
v. & Gross margin (iv - i) & 37277 & 56242 & 5408 & 46961 \\
vi. & Net return (iv - iii) & 28303 & 30697 & 1913 & 44947 \\
vii. & BCR (iv $\div$ iii) & 1.27 & 1.26 & 1.26 & 2.12 \\
\hline
\end{tabular}

Source: Authors' estimation, 2016.

It is apparent from Table 4 that there was a distinguishable difference in terms of productivity and profitability of different agricultural enterprises like crop, livestock, poultry and fish catching in Haor areas and main land which were also statistically significant. The findings are faintly similar with Uddin and Dhar (2017) where the authors revealed that crop, livestock and poultry were found profitable under C-L-P farming 
system, where homestead and agroforestry was found profitable under C-L-HA farming system; and the differences in productivity of agricultural enterprises between Char land and main land were found significant in most of the cases.

Table 4. Productivity and profitability of different agricultural enterprises

\begin{tabular}{|c|c|c|c|c|c|c|c|}
\hline \multirow{2}{*}{\multicolumn{2}{|c|}{ Enterprises }} & \multicolumn{3}{|c|}{ Productivity } & \multicolumn{3}{|c|}{ Profitability } \\
\hline & & Haor area & Main land & Difference & Haor area & Main land & Difference \\
\hline \multicolumn{2}{|c|}{ Crop (kg/ha, Tk./ha) } & 8679 & 7901 & $\begin{array}{c}778 \\
\left(0.041^{* *}\right)^{\mathrm{a}}\end{array}$ & $\begin{array}{c}28303 \\
\text { (BCR: } 1.27)\end{array}$ & $\begin{array}{c}12457 \\
\text { (BCR: } 1.09)\end{array}$ & $\begin{array}{c}15846 \\
(0.071 *)^{\mathrm{a}}\end{array}$ \\
\hline \multirow{2}{*}{ Livestock } & $\begin{array}{c}\text { Milk (litre/animal, } \\
\text { Tk./animal) }\end{array}$ & 125 & 112 & $\begin{array}{c}13 \\
(0.209)^{\mathrm{a}}\end{array}$ & \multirow{2}{*}{$\begin{array}{c}30697 \\
\text { (BCR: } 1.26)\end{array}$} & \multirow{2}{*}{$\begin{array}{c}27173 \\
\text { (BCR: 1.02) }\end{array}$} & \multirow{2}{*}{$\begin{array}{c}3524 \\
(0.092 *)^{\mathrm{a}}\end{array}$} \\
\hline & $\begin{array}{c}\text { Meat (kg/animal, } \\
\text { Tk/animal) }\end{array}$ & 21 & 19 & $\begin{array}{c}2 \\
(0.318)^{\mathrm{a}} \\
\end{array}$ & & & \\
\hline \multirow{2}{*}{ Poultry } & $\begin{array}{c}\text { Egg (No./bird, } \\
\text { Tk./bird) }\end{array}$ & 69 & 82 & $\begin{array}{c}-13 \\
(0.004 * * *)^{\mathrm{a}}\end{array}$ & \multirow{2}{*}{$\begin{array}{c}1913 \\
\text { (BCR: 1.26) }\end{array}$} & \multirow{2}{*}{$\begin{array}{c}2085 \\
\text { (BCR: } 1.49)\end{array}$} & \multirow{2}{*}{$\begin{array}{c}-172 \\
(0.118)^{\mathrm{a}}\end{array}$} \\
\hline & $\begin{array}{c}\text { Meat }(\mathrm{kg} / \mathrm{bird}, \\
\text { Tk/bird) }\end{array}$ & 3 & 2 & $\begin{array}{c}1 \\
(0.034 * *)^{\mathrm{a}}\end{array}$ & & & \\
\hline \multicolumn{2}{|c|}{$\begin{array}{l}\text { Fish catching } \\
\text { (kg/ha, Tk./ha) }\end{array}$} & 946 & 520 & $\begin{array}{c}426 \\
(0.215)^{\mathrm{a}}\end{array}$ & $\begin{array}{c}44947 \\
\text { (BCR: 2.12) }\end{array}$ & $\begin{array}{c}13615 \\
\text { (BCR: } 1.07)\end{array}$ & $\begin{array}{c}31332 \\
(0.028 * *)^{\mathrm{a}}\end{array}$ \\
\hline
\end{tabular}

Source: Authors' estimation, 2016.

Note: ${ }^{\mathrm{a}} \mathrm{p}$-value; $* * *, * *$ and $*$ indicate significant at $1 \%, 5 \%$ and $10 \%$ probability level, respectively.

Factor share of income from different enterprises

Table 5 depicts factor share of income from different enterprises. It is seen that producers' share was the highest in all the enterprises $(42 \%, 47 \%, 46 \%$ and $38 \%$ in crop, livestock, poultry and fishery, respectively) which was followed by labour in case of crop, livestock and fishery $(26 \%, 21 \%$ and $25 \%$, respectively) and capital in case of poultry $(21 \%)$. Valentinyi and Herrendorf (2008) had measured the US income shares of capital and labor for the standard sectors used in multi-sector versions of the growth model and found that these factor income shares differed across sectors, e.g., the capital share of agriculture was more than two and a half times that of construction and more than $50 \%$ larger than that of the aggregate economy.

Table 5. Factor share of income from different enterprises (in percentage)

\begin{tabular}{lcccc}
\hline Factors & Crop & Livestock & Poultry & Fishery \\
\hline Land & 13 & 15 & 14 & 19 \\
Labour & 26 & 21 & 19 & 25 \\
Capital & 19 & 17 & 21 & 18 \\
Producer' share & 42 & 47 & 46 & 38 \\
\hline
\end{tabular}

Source: Authors' estimation, 2016.

Spatial variation in price and quantity of major agricultural inputs and outputs

Table 5 demonstrates spatial variation in price and quantity of major agricultural inputs and outputs between Haor areas and main land. Major differences in quantity of inputs were seen in fingerlings and feed in terms of fish catching; and major differences in price of inputs were in livestock feed, poultry feed and medicine, and fingerlings and feed in terms of fish catching. Also, remarkable differences were identified in the outputs of agricultural enterprises, especially in the final product from fish catching (Table 5). Schnepf (2006) avowed that the general price level of an agricultural commodity, whether at a major terminal, port or commodity futures exchange, is influenced by a variety of market forces that can alter the current or expected balance between supply and demand.

\section{SWOT analysis}

SWOT analysis for business prospects and challenges of farmers is represented in Table 6 . In terms of strengths, $76.7 \%$ respondents stated about favorable farm environment and $71.7 \%$ stated about enterprise interdependence (ranked $1^{\text {st }}$ and $2^{\text {nd }}$, respectively); and in terms of weakness, $75.8 \%$ respondents stated about weak marketing system and $63.3 \%$ stated about lack of agricultural credit access (ranked $1^{\text {st }}$ and $2^{\text {nd }}$, respectively). Considering opportunities, $72.5 \%$ respondents stated about improvement in agricultural technologies and $60.8 \%$ stated about proper utilization of agricultural resources (ranked $1^{\text {st }}$ and $2^{\text {nd }}$, respectively); and in terms of threats, $84.2 \%$ respondents stated about environmental vulnerability where $80.0 \%$ stated about declining amount of cultivable land (ranked $1^{\text {st }}$ and $2^{\text {nd }}$, correspondingly) (Table 6). Lokesha et al. (2002) found the similar result and exposed that the major strength of agribusiness sector in India includes creating employment opportunities for small and marginal farmers, landless labourers and educated unemployed persons who are specialized in the field of agriculture; and high cost of machineries particularly, the imported machineries and equipments as the major weakness. 
Table 5. Spatial variation in price and quantity of major agricultural inputs and outputs

\begin{tabular}{|c|c|c|c|c|c|c|}
\hline \multicolumn{7}{|l|}{ Crop } \\
\hline \multirow{2}{*}{ Inputs } & \multicolumn{3}{|c|}{ Quantity (kg/ha) } & \multicolumn{3}{|c|}{ Price $(\mathrm{Tk} . / \mathrm{kg})$} \\
\hline & Haor area & Main land & Difference & Haor area & Main land & Difference \\
\hline Seed/seedlings & 42 & 36 & 6 & 300 & 280 & 20 \\
\hline Fertilizers & 42 & 45 & -3 & 23 & 20 & 3 \\
\hline \multirow{2}{*}{ Outputs } & \multicolumn{3}{|c|}{ Quantity (kg/ha) } & \multicolumn{3}{|c|}{ Price (Tk./kg) } \\
\hline & Haor area & Main land & Difference & Haor area & Main land & Difference \\
\hline Final product & 8450 & 8500 & -50 & 16 & 20 & -4 \\
\hline \multicolumn{7}{|l|}{ Livestock } \\
\hline \multirow{2}{*}{ Inputs } & \multicolumn{3}{|c|}{ Quantity } & \multicolumn{3}{|c|}{ Price (Tk./animal) } \\
\hline & Haor area & Main land & Difference & Haor area & Main land & Difference \\
\hline Feed (kg/head/year) & 140 & 125 & 15 & 6500 & 5850 & 650 \\
\hline Artificial insemination & - & - & - & 250 & 300 & -50 \\
\hline Vitamin and medicine & - & - & - & 200 & 150 & 50 \\
\hline \multirow{2}{*}{ Outputs } & \multicolumn{3}{|c|}{ Quantity } & \multicolumn{3}{|c|}{ Price (Tk./animal) } \\
\hline & Haor area & Main land & Difference & Haor area & Main land & Difference \\
\hline No. of livestock & 4 & 6 & -2 & 25000 & 25750 & -750 \\
\hline \multicolumn{7}{|l|}{ Poultry } \\
\hline \multirow{2}{*}{ Inputs } & \multicolumn{3}{|c|}{ Quantity } & \multicolumn{3}{|c|}{ Price (Tk./bird) } \\
\hline & Haor area & Main land & Difference & Haor area & Main land & Difference \\
\hline Feed & - & - & - & 1300 & 1100 & 200 \\
\hline Vitamin and medicine & - & - & - & 200 & 400 & -200 \\
\hline \multirow{2}{*}{ Outputs } & \multicolumn{3}{|c|}{ Quantity } & \multicolumn{3}{|c|}{ Price (Tk./bird) } \\
\hline & Haor area & Main land & Difference & Haor area & Main land & Difference \\
\hline Final product & - & - & - & 7500 & 8600 & 1100 \\
\hline \multicolumn{7}{|l|}{ Fish catching } \\
\hline \multirow{2}{*}{ Inputs } & \multicolumn{3}{|c|}{ Quantity } & \multicolumn{3}{|c|}{ Price (Tk./ha) } \\
\hline & Haor area & Main land & Difference & Haor area & Main land & Difference \\
\hline Human labour (no./ha/day) & 10 & - & 10 & 3000 & - & 3000 \\
\hline Fingerlings (no./ha) & - & 3600 & -3600 & - & 105240 & -105240 \\
\hline Feed (kg/ha) & - & 2300 & -2300 & - & 705000 & -705000 \\
\hline Capital cost (Tk./ha) & - & - & - & 2000 & 1200 & 800 \\
\hline Water supply & - & - & - & - & 30250 & -30250 \\
\hline \multirow{2}{*}{ Outputs } & \multicolumn{3}{|c|}{ Quantity (kg/ha) } & \multicolumn{3}{|c|}{ Price (Tk./ha) } \\
\hline & Haor area & Main land & Difference & Haor area & Main land & Difference \\
\hline Final product & 20700 & 15480 & 5220 & 1845620 & 1786350 & 59270 \\
\hline
\end{tabular}

Source: Authors' estimation based on field survey, 2016.

Table 6. SWOT analysis for business prospects and challenges of farmers

\begin{tabular}{|c|c|c|c|c|c|}
\hline Statements & $\begin{array}{c}\% \text { of } \\
\text { farmers }\end{array}$ & Rank & Statements & $\%$ of farmers & Rank \\
\hline \multicolumn{3}{|l|}{ Strengths } & \multicolumn{3}{|c|}{ Weakness } \\
\hline Increased farm productivity & 53.3 & 3 & Scarcity in input availability & 57.5 & 3 \\
\hline $\begin{array}{l}\text { Enterprise interdependence in the form } \\
\text { of input-output relationship }\end{array}$ & 71.7 & 2 & High price of inputs & 40.0 & 4 \\
\hline Favorable farm environment & 76.7 & 1 & Weak marketing system & 75.8 & 1 \\
\hline Sufficient workforce & 49.2 & 4 & Lack of agricultural credit access & 63.3 & 2 \\
\hline \multicolumn{3}{|l|}{ Opportunities } & \multicolumn{3}{|l|}{ Threats } \\
\hline $\begin{array}{l}\text { Improvement in agricultural } \\
\text { technologies }\end{array}$ & 72.5 & 1 & Price fluctuation & 64.2 & 4 \\
\hline Diversification in farming practices & 57.5 & 3 & Environmental vulnerability & 84.2 & 1 \\
\hline $\begin{array}{l}\text { Proper utilization of agricultural } \\
\text { resources }\end{array}$ & 60.8 & 2 & $\begin{array}{l}\text { Declining amount of cultivable } \\
\text { land }\end{array}$ & 80.0 & 2 \\
\hline $\begin{array}{l}\text { Market potential for value added } \\
\text { agricultural products }\end{array}$ & 45.0 & 4 & $\begin{array}{l}\text { Land transformation from } \\
\text { cropland to others }\end{array}$ & 68.3 & 3 \\
\hline
\end{tabular}

Source: Field survey, 2016.

\section{Business prospects in the study areas}

The findings demand to develop some forms of agribusiness activities based on local agriculture and rural community which ultimately contribute for the betterment of Haor economy, farmers' income generation and livelihood improvement. From the field level experiences, the researchers found lack of responsibility of the local extension agents in terms of giving input support to the farmers which ultimately caused reliance of the farmers to the private sector. 


\section{Input packages}
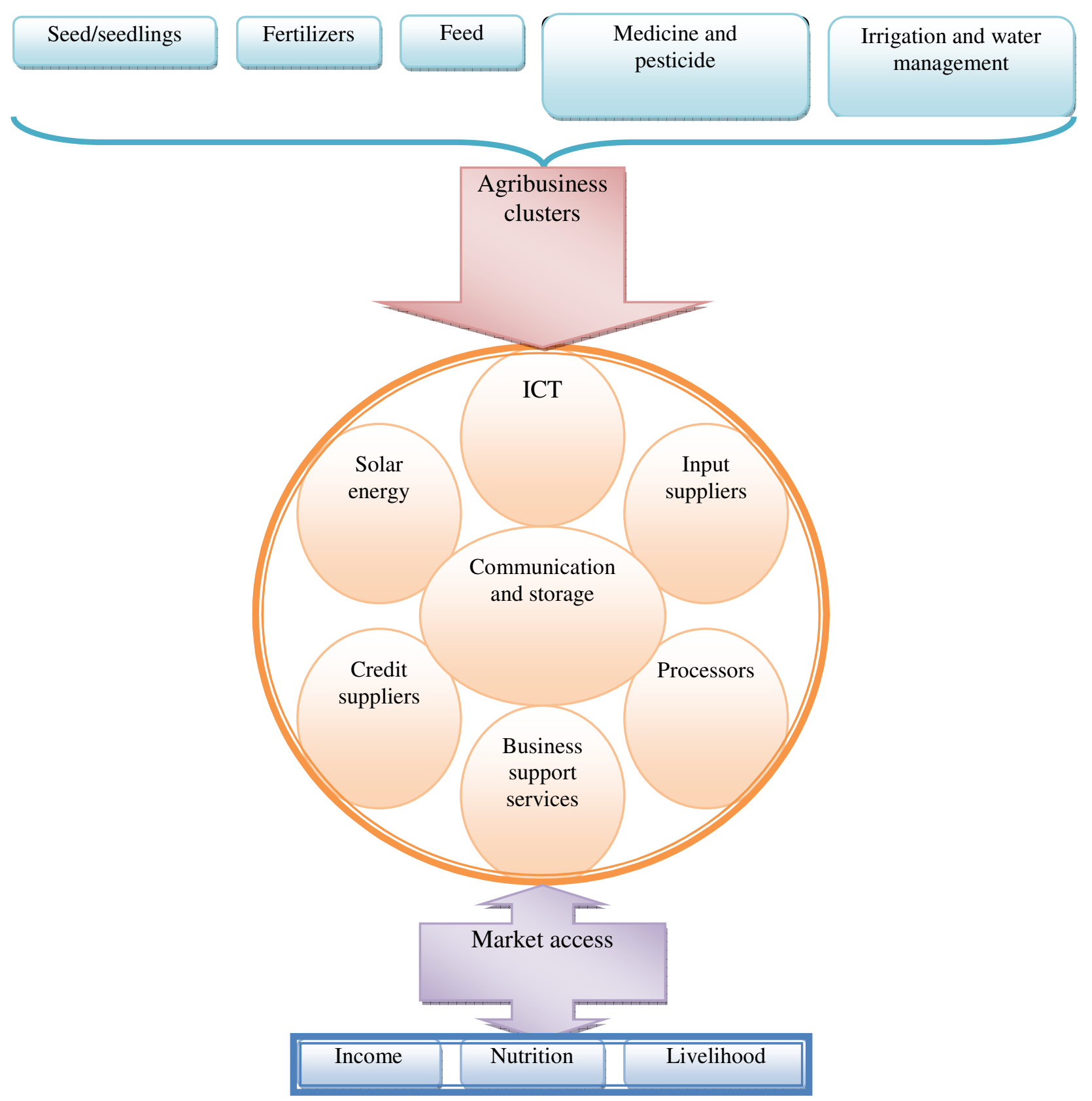

Diagram 1: Conceptual framework of business perspectives in haor areas

Diagram 1 depicts that targeting on crucial agricultural input packages, agribusiness clusters with the involvement of input suppliers, credit/financial organizations, different support service providers will be formed. Such supportive business environment will contribute notably for farmers' employment creation and income generation. Thereby, farmers' market access will be easier through more income yielding from different agricultural enterprises, better nutrition will be ensured and livelihood of the Haor people will be improved. Tersoo (2013) supported this concept where the author declared that the farm, non-farm and processing components of agribusiness are capable of generating jobs, provision of income, poverty reduction and infrastructural growth in Nigeria.

\section{Considerable issues of agribusiness and future opportunities}

The study areas hold a high agribusiness environment with plenty of local resources. Higher local and regional demand for good quality agricultural energy inputs (i.e., fertilizers, pesticides, feed, etc.) has created possible opportunities for fertilizers and pesticides industries, feed mills, etc. Now-a-days, modern agricultural equipments and machineries create crying need to these areas. Increased rice productivity and large amount of 
fish availability in the Haor areas show great prospects of establishing rice mills and fish processing industries (Table 7).

However, to address whether the agribusiness venture has a good business opportunity, it is necessary to analyze adequately the factors like potential market for the proposed business, economic availability of sufficient raw product and the production process as well as environmental conditions with the availability of facilities and services to be required by the proposed venture. The venture has the potential to be profitable if all of these factors are analyzed adequately. It is also important to consider the challenges as: price fluctuation, environmental vulnerability, declining amount of cultivable land, land transformation, etc. and so on.

Table 7. Available resources and extent of agribusiness opportunity

\begin{tabular}{|c|c|c|c|c|c|c|}
\hline \multirow{2}{*}{$\begin{array}{l}\text { Enterprises } \\
\text { involved }\end{array}$} & \multirow{2}{*}{$\begin{array}{c}\text { Avenue of } \\
\text { agribusiness } \\
\text { potential }\end{array}$} & \multirow[t]{2}{*}{ Available resources } & \multirow[t]{2}{*}{ Considerable issues } & \multicolumn{3}{|c|}{$\begin{array}{l}\text { Extent of opportunity based on } \\
\text { researchers' observation }\end{array}$} \\
\hline & & & & High & Medium & Low \\
\hline \multirow{3}{*}{ Crop } & $\begin{array}{l}\text { Fertilizers and } \\
\text { pesticides industries }\end{array}$ & $\begin{array}{l}\text { Labour abundance } \\
\text { and availability of } \\
\text { quality ingredients }\end{array}$ & $\begin{array}{l}\text { Higher demand and market } \\
\text { price, and employment } \\
\text { opportunities }\end{array}$ & & $\sqrt{ }$ & \\
\hline & $\begin{array}{l}\text { Seed processing } \\
\text { industries }\end{array}$ & $\begin{array}{l}\text { Availability of high } \\
\text { quality grains }\end{array}$ & $\begin{array}{l}\text { Lack quality seed and } \\
\text { demand for high yielding } \\
\text { variety seeds }\end{array}$ & & \multirow{6}{*}{$\sqrt{ }$} & $\sqrt{ }$ \\
\hline & Rice mills & $\begin{array}{l}\text { Higher rice } \\
\text { productivity and } \\
\text { labour availability }\end{array}$ & $\begin{array}{l}\text { Risk of paddy damage and } \\
\text { immediate course of action, } \\
\text { and higher demand for } \\
\text { processed grains }\end{array}$ & $\sqrt{ }$ & & \\
\hline $\begin{array}{l}\text { Livestock and } \\
\text { poultry }\end{array}$ & Feed mills & $\begin{array}{l}\text { Availability of } \\
\text { quality ingredients }\end{array}$ & $\begin{array}{l}\text { Demand for quality feed; } \\
\text { and lack of specialized feed } \\
\text { for each of livestock and } \\
\text { poultry }\end{array}$ & & & \\
\hline Fish catching & $\begin{array}{l}\text { Fish processing } \\
\text { industries }\end{array}$ & $\begin{array}{l}\text { Plenty of different } \\
\text { kinds of fishes }\end{array}$ & $\begin{array}{l}\text { Higher demand of processed } \\
\text { fish and export potential }\end{array}$ & $\sqrt{ }$ & & \\
\hline \multirow[t]{2}{*}{$\begin{array}{l}\text { All agricultural } \\
\text { enterprises }\end{array}$} & $\begin{array}{l}\text { Agricultural } \\
\text { equipment and } \\
\text { machinery industries }\end{array}$ & $\begin{array}{l}\text { Availability of } \\
\text { manpower, and } \\
\text { equipment } \\
\text { producing and } \\
\text { processing } \\
\text { elements }\end{array}$ & $\begin{array}{l}\text { Lack of necessary } \\
\text { agricultural equipments and } \\
\text { machineries in time, and } \\
\text { higher demand and market } \\
\text { price }\end{array}$ & $\sqrt{ }$ & & \\
\hline & $\begin{array}{l}\text { Transportation } \\
\text { vehicles and storage }\end{array}$ & $\begin{array}{l}\text { Availability of } \\
\text { labour and scope of } \\
\text { investment }\end{array}$ & $\begin{array}{l}\text { Higher demand due to } \\
\text { product perishability }\end{array}$ & $\sqrt{ }$ & & \\
\hline
\end{tabular}

Source: Researchers' observation, 2016.

\section{Recommendations for policy intervention}

The recommendations based on intervention points in accordance with respondents' agreement are represented in Table 8. It is experienced that $81.5 \%$ respondents agreed with formation of contract based cooperative groups for fair output price and $76.8 \%$ respondents agreed with establishment of seed bank and fertilizer depository. Other recommendations were provision of agricultural incentives for reducing migration rate and usage of appropriate vehicles (according to $39.7 \%$ and $46.4 \%$ farmers, respectively) (Table 8 ).

Table 8. Recommendation matrix

\begin{tabular}{|c|c|c|c|}
\hline Points to be intervened & Recommendations & Facts of consideration & $\begin{array}{l}\text { Agreement of } \\
\text { respondents }(\%)\end{array}$ \\
\hline $\begin{array}{l}\text { Agricultural inputs (e.g., seed } \\
\text { and fertilizer) }\end{array}$ & $\begin{array}{c}\text { Establish seed bank and fertilizer } \\
\text { depository }\end{array}$ & $\begin{array}{c}\text { Research and extension } \\
\text { needed }\end{array}$ & 76.8 \\
\hline Fair output price & $\begin{array}{l}\text { Form contract based cooperative } \\
\text { groups }\end{array}$ & $\begin{array}{l}\text { Policy intervention } \\
\text { needed }\end{array}$ & 81.5 \\
\hline $\begin{array}{l}\text { Motivation of agricultural } \\
\text { labour }\end{array}$ & $\begin{array}{l}\text { Provide agricultural incentives } \\
\text { for reducing migration rate }\end{array}$ & $\begin{array}{l}\text { GO-NGO support } \\
\text { needed }\end{array}$ & 39.7 \\
\hline $\begin{array}{l}\text { Mode of transportation and } \\
\text { storage }\end{array}$ & $\begin{array}{l}\text { Use appropriate vehicles } \\
\text { considering road condition and } \\
\text { establish cold storage }\end{array}$ & $\begin{array}{c}\text { Public private } \\
\text { partnership needed }\end{array}$ & 46.4 \\
\hline
\end{tabular}

Source: Field survey, 2016. 


\section{Conclusion}

The study concludes that the business environment in the Haor areas has a high potential to be exposed with the integration of available local agricultural resources. This can contribute to the improvement of livelihood of the people living in Haor areas. The people of the study areas were dependent on fish catching along with other activities in the Haors which was supported by crop production, livestock rearing and poultry farming. Involvement with these agricultural enterprises was comparatively profitable and productive in Haor areas compared to the main land. Considering the findings, several issues have been arisen to think which are: government price support and improved market management are needed for availability and applicable use of agricultural inputs, and support from GOs and NGOs for managing local productive resources in use of business prospects in the study areas. Moreover, organization of seminars and workshops are necessary to build awareness of the respondents for overcoming the constraints.

\section{References}

Alam, M.S, Quayum, M.A. and Islam, M.A. 2011. Crop production in the haor areas of Bangladesh: Insights from farm level survey. The Agriculturists, 8 (2): 88-97. https://doi.org/10.3329/agric.v8i2.7582

Dhar, A.R. 2016. Enhancing farmers' livelihood through adoption of conservation agriculture: A socioeconomic study. MS Thesis, Department of Agricultural Economics, Bangladesh Agricultural University, Mymensingh-2202.

Dillon, J.L. and Hardaker, J.B. 1993. Farm Management Research for Small Farmer Development. FAO, Rome, Italy.

Gürel , E and Tat, M. 2017. SWOT analysis: A theoretical review. The Journal of International Social Research, 10 (51). Available at https://www.researchgate.net/publication/ 319367788_ SWOT_ANALYSIS_A_THEORETICAL_REVIEW (accessed on 16 March 2018).

HIES, 2017. Preliminary report on household income and expenditure survey 2016. Bangladesh Bureau of Statistics, Statistics and Informatics Division, Ministry of Planning, Government of the People's Republic of Bangladesh.

Islam, S., Uddin, M.T., Akteruzzaman, M., Rahman, M. and Haque, M.A. 2011. Profitability of alternate farming systems in Dingapota haor area of Netrokona district. Progressive Agriculture, 22 (1\&2): 223-239.
Khan, M.N.H., Mia, M.Y. and Hossain, M.R. 2012. Impacts of flood on crop production in haor areas of two upazillas in Kishoregonj. Journal of Environmental Science and NaturalResources, 5 (1): 193-198. https://doi.org/10.3329/jesnr.v5i1.11581

Lokesha, H., Achoth, L., Hugar, L.B., Amrutha, C.P. and Deshmanya, J.B. 2002. Agri-business sector in India- A SWOT analysis. Agricultural Marketing, 45 (2): 28-29.

MoWR, 2012. Master plan of haor area. Bangladesh Haor and Wetland Development Board. Ministry of Water Resources, Government of the People's Republic of Bangladesh, 1: $1-55$.

Nowreen, S., Murshed, S.B., Islam, A.K.M.S. and Bhaskaran, B. 2013. Change of future climate extremes for the haor basin area of Bangladesh. 4th International Conference on Water and Flood Management. Institute of Water and Flood Management, Bangladesh University of Engineering and Technology, Dhaka, Bangladesh.

Parvin, M.T. 2013. An economic analysis of farm and non-farm activities and their income lingkages in Dingaputa haor area of Netrokona district. M.S. Thesis, Department of Agricultural Economics, Bangladesh Agricultural University, Mymensingh, Bangladesh.

Schnepf, R. 2006. Price determination in agricultural commodity markets: A primer. Series: RL33204, Library of Congress. Congressional Research Service. Available at digital.library.unt.edu/ark:/67531/metacrs9219/(accessed on 26 November 2018).

Sharma, P.K. 2010. Scenario of haor vulnerabilities and other obstacles for sustainable livelihood development in Nikli upazila. Journal of Bangladesh Agricultural University, 8 (2): 283-290. https://doi.org/10.3329/jbau.v8i2.7939

Tersoo, P. 2013. Agribusiness as a veritable tool for rural development in Nigeria. International Letters of Social and Humanistic Sciences, 14: 26-36. https://doi.org/10.18052/www.scipress.com/ILSHS.14.26

Uddin, M.T. and Dhar, A.R. 2017. Char people's production practices and livelihood status: An economic study in Mymensingh district. Journal of the Bangladesh Agricultural University, 15 (1): 73-86. https://doi.org/10.3329/jbau.v15i1.33532

Valentinyi, Á. and Herrendorf, B. 2008. Measuring factor income shares at the sectoral level. Review of Economic Dynamics, 11: 820-835. https://doi.org/10.1016/j.red.2008.02.003

WB, 2016. GDP growth. World Bank National Accounts Data. The World Bank Country Office, Dhaka, Bangladesh. 